\title{
CARBONIC ANHYDRASE AND ZINC IN PLANT PHYSIOLOGY
}

\author{
Dalila Jacqueline Escudero-Almanza ${ }^{1}$, Dámaris Leopoldina Ojeda-Barrios ${ }^{1 *}$, \\ Ofelia Adriana Hernández-Rodríguez ${ }^{1}$, Esteban Sánchez Chávez², Teresita Ruíz-Anchondo1, \\ and Juan Pedro Sida-Arreola ${ }^{1}$
}

Carbonic anhydrase (CA) (EC: 2.4.1.1) catalyzes the rapid conversion of carbon dioxide plus water into a proton and the bicarbonate ion $\left(\mathrm{HCO}_{3}{ }^{-}\right)$that can be found in prokaryotes and higher organisms; it is represented by four different families Carbonic anhydrase is a metalloenzyme that requires $\mathrm{Zn}$ as a cofactor and is involved in diverse biological processes including $\mathrm{pH}$ regulation, $\mathrm{CO}_{2}$ transfer, ionic exchange, respiration, $\mathrm{CO}_{2}$ photosynthetic fixation, and stomatal closure Therefore, the review includes relevant aspects about CA morphology, oligomerization, and structural differences in the active site. On the other hand, we consider the general characteristics of $\mathrm{Zn}$, its geometry, reactions, and physiology. We then consider the CA catalysis mechanism that is carried out by the metal ion and where Zn acts as a cofactor. Zinc deficiency can inhibit growth and protein synthesis, and there is evidence that it reduces the CA content in some plants, which is a relationship addressed in this review. In leaves, CA represents $20.1 \%$ of total soluble protein, while it is the second most abundant in the chloroplast after ribulose 1,5-disphosphate carboxylase/oxygenase (RuBisCO). This facilitates the supply of $\mathrm{CO}_{2}$ to the phosphoenolpyruvate carboxylase in $\mathrm{C} 4$ and $\mathrm{CAM}$ plants and RuBisCO in $\mathrm{C} 3$ plants.

Key words: Cofactor, metal ion catalysis, metalloenzyme, zinc deficiency, $\mathrm{CO}_{2}$ transfer.

$\mathrm{P}$ lant physiology depends on diverse metabolic processes involving a large number of enzymes which, in turn, also depend on other elements such as cofactors or coenzymes to be activated and catalyzed. One of the many enzymes involved in physiological processes is carbonic anhydrase (CA). In plants, CA helps to elevate $\mathrm{CO}_{2}$ concentration in the chloroplast to increase the carboxylation rate of the RuBisCO enzyme (ribulose 1,5-disphosphate carboxylase). This is the reaction that incorporates $\mathrm{CO}_{2}$ into carbohydrates during photosynthesis and can only use the $\mathrm{C}$ in $\mathrm{CO}_{2}$ instead of carbonic acid or bicarbonate. There are several forms of $\mathrm{CA}$ in nature; in the case of plants, we find $\beta$ carbonic anhydrase, which is a metalloenzyme that requires $\mathrm{Zn}^{2+}$ for its activity. The catalytic mechanism of CA is achieved by the metal ion, and a characteristic of metal ion catalysis is manifested by $\mathrm{CO}_{2}$ hydration through a mechanism binding Zn to hydroxide (Kimber and Pai, 2000). Zinc deficiency may inhibit growth by reducing the available

${ }^{1}$ Universidad Autónoma de Chihuahua, Facultad de Ciencias Agrotecnológicas, Escorza 900. Col. Centro. 31000. Apartado Postal 24 Chihuahua, Chihuahua, México.

*Corresponding author (dojeda@uach.mx).

${ }^{2}$ Centro de Investigación en Alimentación y Desarrollo, A.C. Av. $4^{\text {ta }}$ Sur 3820, Fracc. Vencedores del Desierto. 33089. Cd. Delicias, Chihuahua, México.

Received: 7 June 2011.

Accepted: 3 January 2012
$\mathrm{Zn}$ content in the plant, which directly affects metabolism by altering the balance of other nutrients in the plants, such as iron, $\mathrm{P}$, and $\mathrm{Cu}$. The effect of $\mathrm{Zn}$ deficiency in CA cannot be selective because it causes a general decrease in protein synthesis. However, the association of $\mathrm{Zn}$ with $\mathrm{CA}$ has been reported years ago in crops such as Pisum sativum L., Lactuca sativa L., Petroselinum crispum (Mill.) Fuss, and Spinacia oleracea L. (Tobin, 1970). Subsequent studies also report such associations of $\mathrm{Zn}$ with CA in pecan Carya illinoinensis (Wangenh.) K. Koch (Snir, 1983) and rice (Oryza sativa L.) (Sasaki et al., 1998). Although studies have been performed with $\mathrm{CA}$, it is not being used in a practical way as a nutritional diagnostic test to detect $\mathrm{Zn}$ deficiency. Thus, this paper aims to differentiate the biochemical processes that exist between $\mathrm{CA}$ and $\mathrm{Zn}$ in plant physiology, as well as the theoretical elements needed to develop and implement new nutritional diagnostic techniques that establish the state of the art on this matter with the hope of benefits for technological development.

\section{General aspects of carbonic anhydrase}

Carbonic anhydrase or carbonate dehydratase (CA, EC: 4.2.1.1), is a type of enzyme that catalyzes the rapid conversion of $\mathrm{CO}_{2}$ over water in a proton and bicarbonate ion $\left(\mathrm{HCO}_{3}^{-}\right)$.

$$
\mathrm{CO}_{2}+\mathrm{H}_{2} \mathrm{O} \leftrightarrow+\mathrm{HCO}_{3}{ }^{-}+\mathrm{H}^{+}
$$

This reaction is quite slow without the $\mathrm{CA}$ biological 
catalyst since the reaction with the enzyme is normally conducted from 10 thousand to 1 million times per second (Hewett-Emmett and Tashian, 1996). Carbonic anhydrase was found in bovine erythrocytes by Meldrum and Roughton in 1933 and Neish accidentally discovered the first $\beta$ carbonic anhydrase as a component of the chloroplast of the plant leaf in 1939. Only CA families have been well characterized as catalysts in cells and tissue in all forms of life. Based on its amino acid sequence of carbonic anhydrases (CAs), it can be classified into three separate families designated as alpha, beta, and gamma (HewettEmmett and Tashian, 1996). It should be noted that plant leaf chloroplast CA was not recognized as a different form of CA, evolutionarily and structurally, until five decades later with the advent of DNA sequencing. At that time, it was the second known evolutionarily different form of CA and was therefore designated as $\beta$. Since 1990, many authors have shown the presence of $\beta$-CA not exclusively in photosynthetic organisms, but also in eubacteria, yeast, and archaea species (Smith and Ferry, 2000; Moroney et al., 2001; Elleuche and Poggeler, 2009).

\section{Importance of $\boldsymbol{\beta}-\mathrm{CA}$}

Demonstrating the physiological role of $\beta$-AC has been somewhat elusive, although it is likely to be a very important accessory enzyme for different dependent processes of $\mathrm{CO}_{2}$ or $\mathrm{HCO}_{3}^{-}$such as processes that include other enzymatic reactions, e.g., catalysis carried out by $\mathrm{RuBisCO}$ in chloroplasts, kinase in Escherichia coli (Guilloton et al., 1992), Helicobacter pylori urease (Nishimori et al., 2008), and bicarbonate-dependent carboxylase in Corynebacterium glutamicum (Mitsuhashi et al., 2004). Beta-CA is an essential component of carboxysome, an organelle with high $\mathrm{CO}_{2}$ concentrations in cyanobacteria. Some $\beta$-AC mutations have produced a phenotype that requires high $\mathrm{CO}_{2}$ concentrations for growth (Fukuzawa et al., 1992). It has also been shown that $\beta$-CA is essential for the growth of E. coli (Merlin et al., 2003), C. glutamicum (Mitsuhashi et al., 2004), and Saccharomyces cerevisiae (Gotz et al., 1999). Under aerobic conditions and atmospheric $\mathrm{CO}_{2}$ concentrations, it has been demonstrated that the native type or variants of the catalytic component of $\beta-\mathrm{CA}$ in $S$. cerevisiae can restore the organism's ability to grow under aerobic conditions (Clark et al., 2004).

\section{Structure of $\beta$-CA}

After recognizing the existence of $\beta-\mathrm{CA}$ as a structurally independent form of the enzyme, it took a decade to get a crystal structure of a $\beta$-CA X-ray. This was mainly because $\beta$-CAs in plants are somewhat difficult to handle and very sensitive to air oxidation. The first report of the $\beta$-CA X-ray structure was the red algae Porphyridium purpureum (Mitsuhashi et al., 2000). This was quickly followed by the structure of the Pisum sativum plant (Kimber and Pai, 2000) and E. coli bacteria (Cronk et al., 2001). All CAs $\alpha / \beta$ share a fold that is not found in other proteins. Although $\beta$-CAs can have a variety of oligomeric states, their molecular masses range between 45 and $200 \mathrm{kDa}$, and the fundamental structural unit of the $\beta$-CA appears as a dimer or its structural equivalent (Mitsuhashi et al., 2000). Just like any other kind of CA, $\beta$-CA exposures show a broad structural and functional diversity. All $\beta$-CAs share a common structural element, which is a parallel central $\beta$ sheet made up of four filaments 2-1-3-4 arranged within each monomer or pseudo-monomer. The fundamental dimer is closely intertwined, and there are extensive monomer-monomer contacts in the region where it joins with the $\beta$ sheet. Almost all $\beta$-CAs are structurally characterized by a $\mathrm{Zn}$ ion in each monomer or pseudo-monomer (Figure 1). The $\mathrm{Zn}$ ion is found in a pseudo-tetrahedral environment of the Cys2His $(\mathrm{X})$ coordination type, where $\mathrm{X}$ is water, an anion, or an Asp residue. This $\mathrm{Zn}$ ion defines the active site of the enzyme (Krissinel and Henrick, 2007).

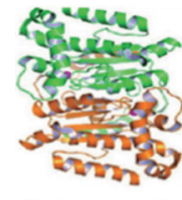

Escherichia coli

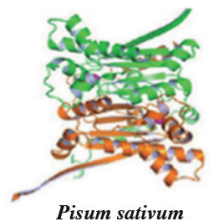

Pisum sativum

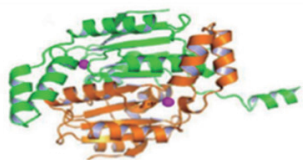

Methanobacterium thermoautotrophicum
Figure 1. Ribbon diagram of carbonic anhydrase fundamental structure obtained by X-ray crystallography, which is manifested as a dimer with monomers shown in orange and green. The $\mathrm{Zn}$ ions are shown as magenta spheres (Kimber and Pai, 2000).

\section{Structural classes of $\beta$-CAs: Type I and Type II}

The $\beta$-CA structures obtained by $\mathrm{X}$-ray crystallography can be classified into two different structural classes based on the organization of the active site in their uncomplexed state, referred to as "type I" and "type II" $\beta$-CAs. The main difference between these two types of $\beta$-CAs is the binding of $\mathrm{Zn}$ ions to the active site, and the orientation and organization of the surrounding residues (Figure 2). Type I $\beta$-CAs are distinguished by the following characteristics in the active site: (1) a set of four spherically arranged Cys2His $(\mathrm{X})$ coordinates where $\mathrm{X}$ is an interchange ligand (e.g., acetate, acetic acid, water), (2) an Asp-Arg pair that guides the Asp residues into accepting a hydrogen bond
Type I

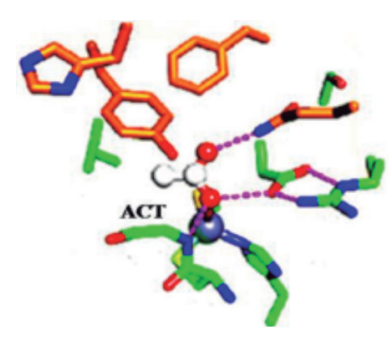

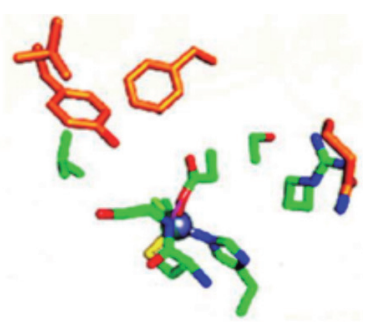

Type II
Figure 2. Structural differences of the $\beta$-carbonic anhydrase active site: Type I and Type II (Rowlett, 2010). 
of interchangeable atoms that are directly linked to $\mathrm{Zn}$ ions, (3) a donor hydrogen bond able to interact with a $\mathrm{Zn}$ bicarbonate ion in the interchangeable position of the ligand, and (4) a narrow and hydrophobic cleft along the dimer interface or pseudo-dimer that leads to the $\mathrm{Zn}$ ions of the active site (Covarrubias et al., 2005; Rowlett, 2010). Type II $\beta$-CAs are characterized by the following distribution in the active site: (1) a closed system of four Cys2HisAsp coordinates forming a coordination sphere with $\mathrm{Zn}$, (2) an Asp-Arg fracture, (3) the lack of a hydrogen bond donor (e.g., Gln or the equivalent of Gln151) able to interact with a bound bicarbonate ion consolidated in the Asp position, and (4) a narrow and hydrophobic cleft along the dimer interface or pseudo-dimer that leads to the $\mathrm{Zn}$ ions of the active site (Covarrubias et al., 2005; Rowlett, 2010).

\section{Isoenzymes}

Enzymes usually have multiple forms by varying their molecular mass and metabolism regulation activities. These forms are called isoenzymes; they play a major role in the adaptation of organisms and are used as biochemical co-dominant markers to identify genotypes and establish phylogenetic relationships among different groups of taxa. Carbonic anhydrase isoenzymes have been determined in the 24 monocot and dicot plant species (Atkins et al., 1972).

\section{Oligomerization of $\boldsymbol{\beta}-\mathrm{CA}$}

In biological systems, proteins rarely act alone and usually bind to other biomolecules (often other proteins) to form oligomers and provide cellular-specific responses. We talk about homo-oligomers if the subunits are identical and hetero-oligomers if they are different. Many of these protein-protein associations are involved in diverse chain reactions in the cellular processes. Among the oligomeric forms found in nature that structurally characterize $\beta-\mathrm{CA}$ are dimers, tetramers, and octamers (Figure 3). The state of oligomerization seems to be driven by surface extensions or unique elaboration of the secondary structure of the $\beta$-CA core (Kimber and Pai, 2000; Krissinel and Henrick, 2007).

\section{Overview of Zn}

The atomic number of $\mathrm{Zn}$ is 30 ; it works with a valence of +2 and an atomic weight of 65.37 u.ma, an electron configuration [Ar] $3 \mathrm{~d}^{10} 4 \mathrm{~s}^{2}$ belonging to period 4 and group
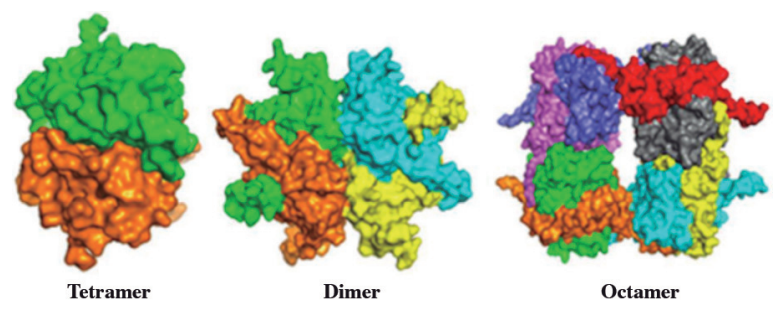

Figure 3. Oligomeric forms of $\beta$-carbonic anhydrase (Rowlett, 2010).
IIB (Williams, 1987). Zinc is a metal that is sometimes classified as a transition metal, although strictly speaking it is not since $\mathrm{Zn}$ and its type of device have full d orbitals. This element resembles $\mathrm{Mg}$ and $\mathrm{Cd}$ in their group, but $\mathrm{Hg}$ is far away due to its unique physical and chemical properties (lanthanide contraction and powerful relativistic effects on linking orbitals). It is a chemically active metal; it produces a blue greenish flame when burning that releases Zn oxide as smoke (Barak and Helmke, 1993). It is number 23 in the list of the most abundant elements on earth and has five isotopes: ${ }^{64} \mathrm{Zn}(48.63 \%),{ }^{66} \mathrm{Zn}(27.90 \%)$, ${ }^{67} \mathrm{Zn}(4.90 \%),{ }^{68} \mathrm{Zn}(18.75 \%)$, and ${ }^{70} \mathrm{Zn}(0.62 \%)$. In plants, it has been reported that there are fractions of heavy isotopes in the roots and light isotopes in the shoots (Weiss et al., 2005). Zinc in solution is in the +2 oxidation state and, unlike $\mathrm{Cu}^{+2}$ and $\mathrm{Fe}^{+2}$, is electronically stable under physiological conditions as a result of its electrons being in the complete d orbital (Auld, 2001). In addition, $\mathrm{Zn}^{+2}$ has strong characteristics of Lewis acid due to its small load radius $(0.83 \mathrm{~A})$, and it can form strong covalent bonds with S, N, and O donors (Barak and Helmke, 1993; Auld, 2001). Zinc forms many soluble salts including halides, sulfates, nitrates, formates, acetates, thiocyanates, perchlorates, fluorosilicates, cyanides, zincates with alkali metals, and $\mathrm{Zn}$-ammonia salts. On the other hand, it also forms moderate soluble compounds including $\mathrm{Zn}$-ammonium phosphate, $\mathrm{Zn}$ hydroxide, and $\mathrm{Zn}$ carbonate, along with a series of soluble and insoluble organic compounds (Barak and Helmke, 1993).

\section{Zinc properties}

The inherent chemical potential and reactivity of $\mathrm{Zn}$ are not exceptional compared to other metals. However, unlike other transition elements from the first row metals (e.g., $\mathrm{Sc}^{2+}, \mathrm{Ti}^{2+}, \mathrm{V}^{2+}, \mathrm{Cr}^{2+}, \mathrm{Mn}^{2+}, \mathrm{Fe}^{2+}, \mathrm{Co}^{2+}, \mathrm{Ni}^{2+}$, and $\left.\mathrm{Cu}^{2+}\right)$, the $\mathrm{Zn}$ ion $\left(\mathrm{Zn}^{2+}\right)$ contains the full $\mathrm{d}$ orbital $(\mathrm{d} 10)$ and therefore, does not participate in redox reactions, but rather acts as a Lewis acid by accepting a pair of electrons (Williams, 1987). This lack of redox activity produces a stable $\mathrm{Zn}^{2+}$ ion in a biological sense where the potential is in constant flux. Therefore, the $\mathrm{Zn}$ ion is an ideal metal cofactor for reactions requiring a stable redox ion to function as a Lewis acid and as a catalyst in proteolysis and $\mathrm{CO}_{2}$ hydration (Butler, 1998). In addition, due to the filling of the d orbitals, $\mathrm{Zn}^{2+}$ has zero ligand field stabilization energy in all its geometries; therefore, its geometry is inherently more stable than other transition elements (Huheey et al., 1993). This lack of an energy barrier in the coordination geometry can be used by $\mathrm{Zn}$ metalloenzymes to alter metal-ion reactivity and can be an important factor in the ability of $\mathrm{Zn}^{2+}$ to catalyze chemical transformations accompanied by changes in the coordination geometry of the active site. In all the $\mathrm{Zn}$ metalloenzymes studied so far, the most often observed binding geometry is a slightly distorted tetrahedral (Figure 4) with the metal ion coordinated with three or four protein side chains. 


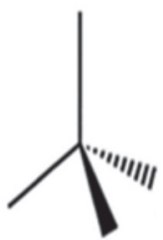

Tetrahedral

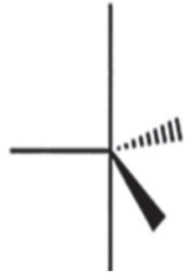

Trigonal bipyramidal

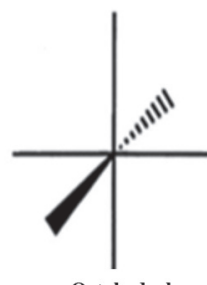

Octahedral
Figure 4. Geometry of zinc (McCall et al., 2000).

However, in other $\mathrm{Zn}$ metalloenzymes, another type of geometry has been observed (McCall et al., 2000).

In the $\mathrm{Zn}$ protein binding sites, the $\mathrm{Zn}$ ion is coordinated by different combinations of the protein side chains (Gregory et al., 1993). In Zn proteins, the role of the $\mathrm{Zn}$ ion is important and can be catalytic, co-catalytic, or structural. In a catalytic $\mathrm{Zn}$ site, $\mathrm{Zn}$ ions directly participate in the reaction. There are several metal ions in close proximity to each other in a co-catalytic $\mathrm{Zn}$ site where $\mathrm{Zn}$ plays a catalytic role, while the other metal ions enhance the site's catalytic activity. Finally, in structural sites, $\mathrm{Zn}$ ions mainly stabilize the tertiary structure of the enzyme in a manner analogous to the disulfide bonds. In all cases, eliminating $\mathrm{Zn}$ can lead to a loss of enzymatic activity (Vallee and Auld, 1993).

\section{Reactions of $\mathbf{Z n}$ with water}

Water bound to $\mathrm{Zn}$ is a crucial component to activate the catalytic site since it can be ionized to form a hydroxide bridge (as in CA), polarized by some base to generate nucleophilic catalysis, or displaced by the substrate (Figure 5). In Zn hydrolases and lyases, such as Zn and $\mathrm{CA}$ proteases, the $\mathrm{Zn}$ ion acts as a powerful electrophilic catalyst (McCall et al., 2000).

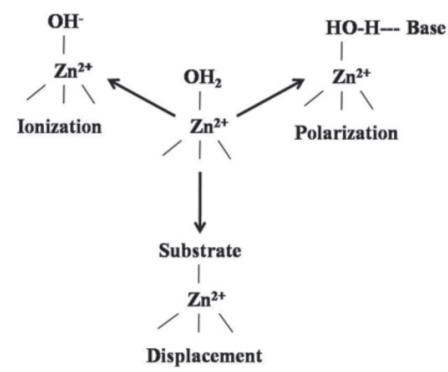

Figure 5. Simplified configuration of zinc reactions with water.

\section{Biochemistry and physiology of $\mathrm{Zn}$}

The mechanism controlling $\mathrm{Zn}$ homeostasis is not exactly known yet (Hacisalihoglu et al., 2004; Broadley et al., 2007; Kramer et al., 2007). However, it has long been acknowledged that $\mathrm{Zn}$ is essential for cell physiological processes (Barak and Helmke, 1993) by influencing different processes as a micronutrient in plants (Figure 6).

On the other hand, in order for $\mathrm{Zn}$ absorption to occur, we have to consider several factors (Figure 7) since micronutrient availability is a function of the "form" in

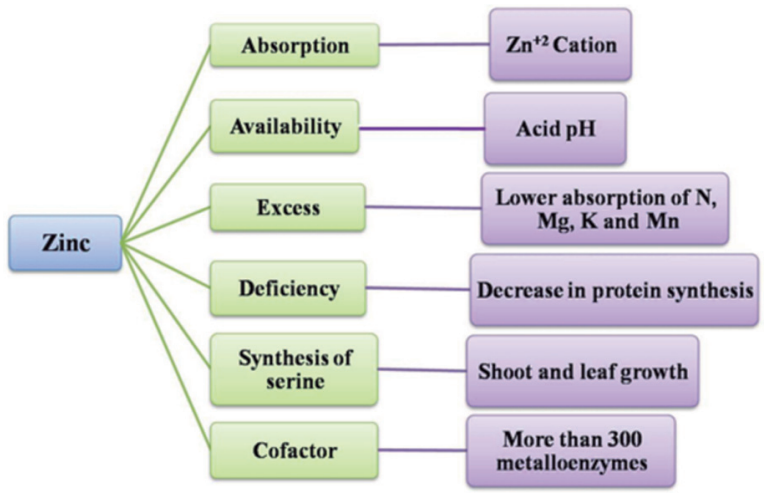

Figure 6. Simplified diagram of $\mathrm{Zn}$ as a plant micronutrient (Sagardoy $\boldsymbol{e t}$ al., 2008; Srivastava and Singh, 2009).

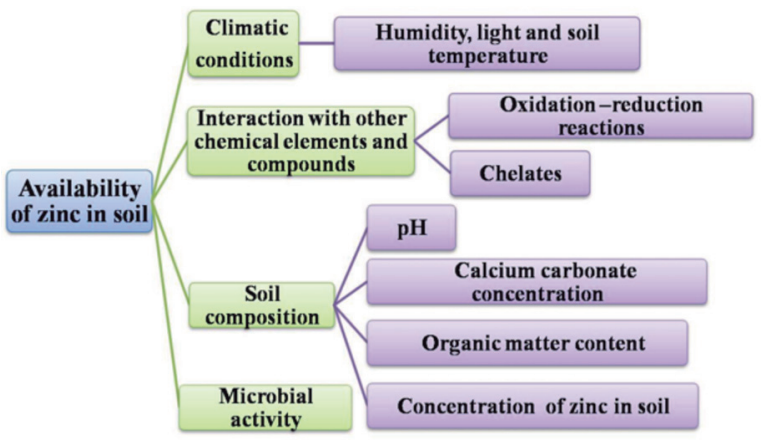

Figure 7. Simplified diagram of factors that influence soil $\mathrm{Zn}$ availability (Alloway, 2004).

which it is found in the soil that determines its "mobility" towards the roots of plants (Ojeda-Barrios et al., 2009). It has also been observed that in alkaline soils with a $\mathrm{pH}$ ranging from 7 to $8.6, \mathrm{Zn}$ is bound by the bicarbonate ion that forms $\mathrm{ZnCO}_{3}$, which is very insoluble. This is why applying $\mathrm{Zn}$ to the soil is not effective and restricted only to non-calcareous soils (Perea-Portillo et al., 2010).

After being captured, $\mathrm{Zn}$ is transported through the xylem where it is chelated by various small molecules (Haydon and Cobbett, 2007) including organic acids such as citrate (Broadley et al., 2007), malate, and nicotinamide (Callahan et al., 2006). When the Zn supply is high, much of this nutrient is also chelated in the cell by organic acids such as malate and citrate (Kupper et al., 2004), amino acids such as histidine (Callahan et al., 2006), phytates, and metallothionein (Papoyan and Kochian, 2004), and the rest is stored in the vacuole (Srivastava and Singh, 2009). Otherwise, different symptoms can be observed when there is Zn deficiency (Figure 8).

\section{Zinc as a cofactor of $\boldsymbol{\beta}$-CA}

The active site which binds the enzyme contains a $\mathrm{Zn}$ ion $\left(\mathrm{Zn}^{2+}\right)$ that reduces $\mathrm{pK}_{\mathrm{a}}$ and allows the nucleophilic attack on $\mathrm{CO}_{2}$. In biological systems, $\mathrm{Zn}$ is found only in the +2 oxidation state. A $\mathrm{Zn}$ atom is always bound to 


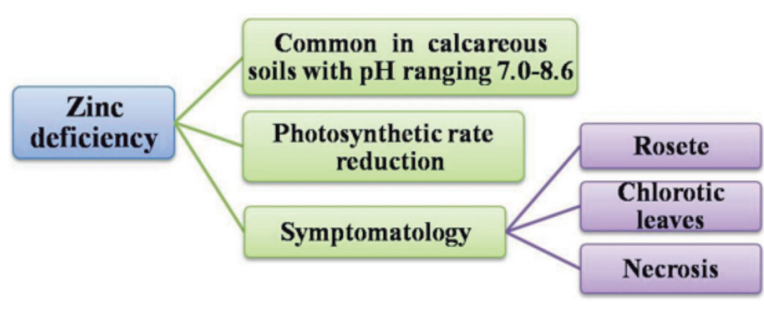

Figure 8. Simplified diagram with zinc deficiency symptoms (PereaPortillo et al., 2010).

four or more ligands; in CA, three coordination sites are occupied by the imidazole rings of three histidine residues and an additional coordination site is occupied by a water molecule (or hydroxide ion, depending on $\mathrm{pH}$ ). The global burden of the $\mathrm{Zn}$ (His) 3 complex remains as +2 since all the molecules that occupy the coordination sites are neutral. Catalysis supposes that $\mathrm{Zn}$ activates water. It was determined by observing the $\mathrm{pH}$ profile in enzymatically catalyzed $\mathrm{CO}_{2}$ hydration where changes in $\mathrm{pH}$ alter the hydration speed of $\mathrm{CO}_{2}$ catalyzed by $\beta$-AC. The enzyme activity is at a maximum at high $\mathrm{pH}$, up to $\mathrm{pH} 8$, where the reaction is near its maximum speed. When $\mathrm{pH}$ decreases, the reaction speed decays. The midpoint of this transition is near $\mathrm{pH} 7$; although many amino acids, mainly histidine, have pka values near 7 , evidence suggests that the group responsible for this transition is not an amino acid without the zinc-bound water molecule (Stryer et al., 2008). The union of a water molecule to the positively charged $\mathrm{Zn}$ site reduces the water molecule pka from 15.7 to 7 . With neutral $\mathrm{pH}$, an important concentration of hydroxide ion (zinc-bound) is generated, which is sufficiently nucleophilic to attack the $\mathrm{CO}_{2}$ much faster than water. The importance of this zinc-bound hydroxide ion suggests a simple mechanism for $\mathrm{CO}_{2}$ hydration.

\section{Catalysis of $\beta$-CA}

A feature of metal ion catalysis is exhibited by $\mathrm{CO}_{2}$ hydration through a mechanism where $\mathrm{Zn}$ is bound to hydroxide. The reaction takes place in four stages: (1) The deprotonation of water where $\mathrm{Zn}$ facilitates the release of a water molecule proton to generate a hydroxide ion. (2) The bonding of $\mathrm{CO}_{2}$ where the $\mathrm{CO}_{2}$ substrate binds the enzyme active site and positions itself to react with the hydroxide ion. (3) The nucleophilic attack of carbon hydroxide on $\mathrm{CO}_{2}$ where the hydroxide ion attacks the $\mathrm{CO}_{2}$ and converts it into the bicarbonate ion. (4) The water displacement of the bicarbonate ion where the catalytic center is regenerated with the release of $\mathrm{HCO}_{3}{ }^{-}$and the bonding of another water molecule (Figure 9). Thus, the binding of water to $\mathrm{Zn}$ favors the formation of the transition state, leading to the formation of bicarbonate and facilitates the release of the proton through the attraction of the two reactants to a close proximity (Stryer et al., 2008).
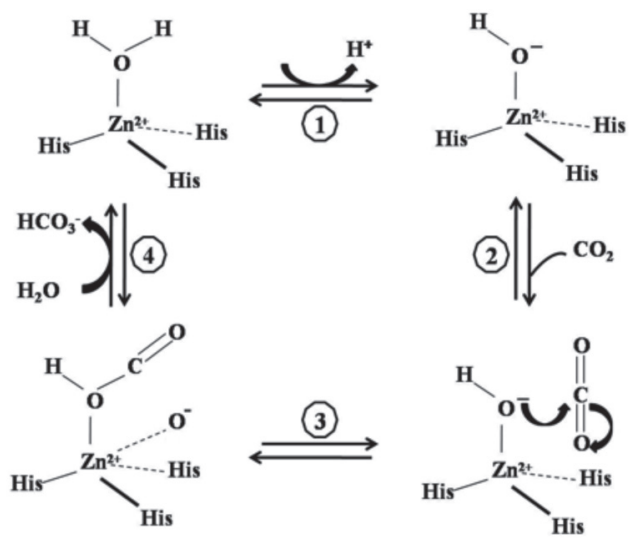

Figure 9. Simplified configuration of $\beta$-carbonic anhydrase catalysis (Stryer et al., 2008).

\section{Role of $\boldsymbol{\beta}$-CA in photosynthesis}

Carbonic anhydrase is involved in a variety of physiological processes (Figure 10) (Smith and Ferry, 2000; Moroney et al., 2001). Any change in CA activity directly affects the photosynthetic rate and $\mathrm{CO}_{2}$ fixation under limited $\mathrm{CO}_{2}$ conditions. Carbonic anhydrase is the only photosynthetic $\mathrm{C}$ metabolism enzyme whose activity fluctuates in a number of species with $\mathrm{CO}_{2}$ concentration changes in the environment. Its activity decreases rapidly into air bubbles at low $\mathrm{CO}_{2}$ emissions and vice versa. The functions of $\mathrm{CA}$ in photosynthetic $\mathrm{CO}_{2}$ fixation are: (1) In $\mathrm{C} 3$ plants, $\beta$-CA helps to raise the $\mathrm{CO}_{2}$ concentration in the chloroplast, which is used as a substrate by the $\mathrm{RuBisCO}$ enzyme, thereby increasing its carboxylation rate and thus participating in the reaction incorporating $\mathrm{CO}_{2}$ into carbohydrates during photosynthesis where $\mathrm{CO}_{2}$ can be used only as $\mathrm{C}$ and not the carbonic acid or the bicarbonate ion. (2) $\mathrm{CO}_{2}$ hydration to form $\mathrm{HCO}_{3}{ }^{-}$is used as a substrate by phosphoenolpyruvate carboxylase (PEPC) in $\mathrm{C} 4$ and CAM plants. (3) $\mathrm{CO}_{2}$ diffusion through the plasma membrane and the chloroplast is facilitated. (4) Participation of active $\mathrm{CO}_{2}$ transport through the plasma of the membrane by converting $\mathrm{CO}_{2}$ into $\mathrm{HCO}_{3}{ }^{-}$is how $\mathrm{C}$ enters the cell (Tiwari et al., 2005).

\section{Stomatal closure}

In absence of the light phase of photosynthesis, energy sources to fix $\mathrm{CO}_{2}$ get depleted, while respiration continues and increases $\left[\mathrm{CO}_{2}\right]$ by shifting the central reaction (Figure 11) to the right which diminishes $\mathrm{pH}$ causing inactivation of amylase and consequently, starch

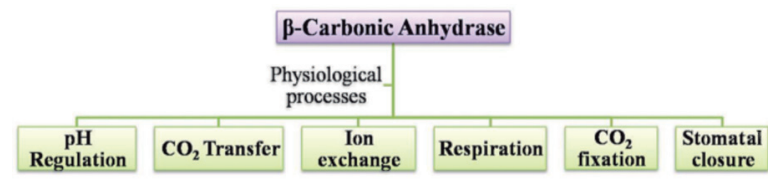

Figure 10. Simplified diagram of physiological processes involving $\beta$-carbonic anhydrase (Smith and Ferry, 2000; Moroney et al., 2001; Tiwari et al., 2005). 


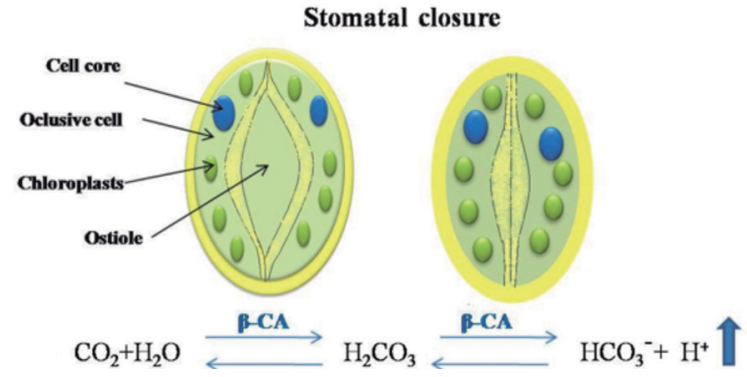

Figure 11. Simplified diagram of the central reaction for stomatal closure.

and glucose are not hydrolyzed any more, resulting in a decrease in the osmotic gradient causing the occlusive cells to lose water and swelling which makes the ostiole to close (Casson and Gray, 2008).

\section{CONCLUSIONS}

There is evidence that $\mathrm{Zn}$ deficiency reduces the CA content in some plants and that there is a close relationship between $\mathrm{CA}$ and $\mathrm{Zn}$ in plant physiology. By understanding the biochemical function of $\mathrm{Zn}$ in this type of biological macromolecules, the connection between the detailed biochemical and physiological functions can interrelate with genotypic and phenotypic expressions. Today, there are many available theoretical elements necessary to develop and implement new nutritional diagnostic techniques.

Anhidrasa carbónica y zinc en fisiología vegetal. La anhidrasa carbónica (CA) (EC: 4.2.1.1) cataliza la conversión rápida de dióxido de carbono más agua en un protón y el ion bicarbonato $\left(\mathrm{HCO}_{3}^{-}\right)$; la cual puede encontrarse en procariotas y en organismos superiores y está representada por cuatro familias distintas. La CA es una metaloenzima que requiere $\mathrm{Zn}$ como cofactor y está implicada en diversos procesos biológicos, incluyendo la regulación del $\mathrm{pH}$, la transferencia de $\mathrm{CO}_{2}$, intercambio iónico, la respiración, la fijación fotosintética de $\mathrm{CO}_{2}$, y el cierre estomático. Por lo cual, la revisión incluye aspectos relevantes sobre la morfología de la AC, su oligomerización y diferencias estructurales en el sitio activo. Por otro lado, se consideran las características generales del $\mathrm{Zn}$, su geometría, las reacciones en que participa y su fisiología. Posteriormente se aborda el mecanismo de catálisis de la $\mathrm{AC}$, el cual se lleva a cabo por ion metálico, donde el Zn actúa como cofactor. La deficiencia de $\mathrm{Zn}$ puede inhibir el crecimiento y síntesis de proteínas. Además, existen evidencias de que la deficiencia de $\mathrm{Zn}$ reduce el contenido de la AC en algunas plantas, de ahí la relación abordada en la presente revisión. En las hojas, la AC representa el $20,1 \%$ de la proteína soluble total y en el cloroplasto es la segunda en abundancia, después de la ribulosa 1,5-bisfosfato carboxilasa/oxigenasa (RuBisCO).
Esto facilita el suministro de $\mathrm{CO}_{2}$ a la fosfoenolpiruvato carboxilasa en plantas $\mathrm{C} 4$ y CAM y a la $\mathrm{RuBisCO}$ en las plantas C3.

Palabras clave: Cofactor, catálisis por ion metálico, metaloenzima, deficiencia de zinc, transferencia de $\mathrm{CO}_{2}$.

\section{LITERATURE CITED}

Alloway, B.J. 2004. Zinc in soils and crop nutrition. International Zinc Association, Brussels, Belgium. Available at: www.fertilizer. org/ifacontent/.../1/.../2008_IZA_IFA_ZincInSoils.pdf (accessed November 2010).

Atkins, C.A., B.D. Patterson, and D. Graham. 1972. Plant carbonic anhydrases. I. Distribution of types among species. Plant Physiology 50:214-217.

Auld, D.S. 2001. Zinc coordination sphere in biochemical zinc sites. 271-313 p. Biometals 14. Center for Biochemical and Biophysical Sciences and Medicine and Department of Pathology, Harvard Medical School, Boston, Massachusetts, USA.

Barak, P., and P.A. Helmke. 1993. The chemistry of zinc. 1-13 p. In Robson, A.D. (ed.) Zinc in soil and plants. Kluwer Academic Publishers, Dordrecht, The Netherlands.

Broadley, M.R., P.J. White, J.P. Hammond, I. Zelko, and A. Lux. 2007. Zinc in plants. New Phytologist 173:677-702.

Butler, A. 1998. Acquisition and utilization of transition metal ions by marine organisms. Science 281:207-209.

Callahan, D.L., J.M. Baker, S.P. Kolev, and A.G. Wedd. 2006. Metal ion ligands in hyperaccumulating plants. Journal of Biological Inorganic Chemistry 11:2-12.

Casson, S., and J.E. Gray. 2008. Influence of environmental factors on stomatal development. New Phytologist 178:9-23.

Clark, D., R.S. Rowlett, J.R. Coleman, and D.F. Klessig. 2004. Complementation of the yeast deletion mutant Delta NCE103 by members of the beta class of carbonic anhydrases is dependent on carbonic anhydrase activity rather than on antioxidant activity. Biochemical Journal 379:609-615.

Covarrubias, A.S., A.M. Larsson, M. Hogbom, J. Lindberg, T. Bergfors, C. Bjorkelid, et al. 2005. Structure and function of carbonic anhydrases from Mycobacterium tuberculosis. Journal of Biological Chemistry 280:18782-18789.

Cronk, J.D., J.A. Endrizzi, M.R.Cronk, J.W. O’Neill, and Y.J. Zhang. 2001. Crystal structure of E. coli beta-carbonic anhydrase, an enzyme with an unusual pH-dependent activity. Protein Science 10:911-922.

Elleuche, S., and S. Poggeler. 2009. Evolution of carbonic anhydrases in fungi. Institute of Microbiology and Genetics, Department of Genetics of Eukaryotic Microorganisms, Georg-August University, Göttingen, Germany. Current Genetics 55:211-222.

Fukuzawa, H., E. Suzuki, Y. Komukai, and S. Miyachi. 1992. A gene homologous to chloroplast carbonic anhydrase (icfA) is essential to photosynthetic carbon dioxide fixation by Synechococcus PCC7942, Proceeding of National Academy of Science U.S.A. 89:4437-4441

Gotz, R., A. Gnann, and F.K. Zimmermann. 1999. Deletion of the carbonic anhydrase-like gene NCE103 of the yeast Saccharomyces cerevisiae causes an oxygen-sensitive growth defect. Yeast 15:855-864.

Gregory, D.S., A.C.R. Martin, J.C. Cheetham, and A.R. Rees. 1993. The prediction and characterization of metal binding sites in proteins. Protein Engineering 6:29-35.

Guilloton, M.B., J.J. Korte, A.F. Lamblin, J.A. Fuchs, and P.M. Anderson. 1992. Carbonic anhydrase in Escherichia coli a product of the cyn operon. Journal of Biological Chemistry 267:37313734.

Hacisalihoglu, G., J.J. Hart, C.E. Vallejos, and L.V. Kochian. 2004. The role of shoot-localized processes in the mechanism of $\mathrm{Zn}$ efficiency in common bean. Planta 218:704-711. 
Haydon, M.J., and C.S. Cobbett. 2007. Transporters of ligands for essential metal ions in plants. New Phytologist 174:499-506.

Hewett-Emmett, D., and R.E. Tashian. 1996. Functional diversity, conservation and convergence in the evolution of the alpha, beta and gamma carbonic anhydrase gene families. Molecular Phylogenetics and Evolution 5:50-77.

Huheey, J.E., E.A. Keiter, and R.L. Keiter. 1993. Inorganic chemistry. Principles of structure and reactivity. Vol. 1. $4^{\text {th }} \mathrm{ed}$. Harper Collins College Publishers, New York, USA.

Kimber, M.S., and E.F. Pai. 2000. The active site architecture of Pisum sativum beta-carbonic anhydrase is a mirror image of that of alpha-carbonic anhydrases. European Molecular Biology Organization Journal 19:1407-1418.

Kramer, U., I.N. Talke, and M. Hanikenne. 2007. Transition metal transport. FEBS letters. Max Planck Institute of Molecular and Plant Physiology 581:2263-2272.

Krissinel, E., and K. Henrick. 2007. Inference of macromolecular assemblies from crystalline state. Journal of Molecular Biology 372:774-797

Kupper, H., A. Mijovilovich, W. Meyer-Klaucke, and P.M.H Kroneck. 2004. Tissue and age- dependent differences in the complexation of cadmium and zinc in the cadmium/zinc Hyper accumulator Thlaspi caerulescens (Ganges Ecotype) revealed by X-ray absorption spectroscopy. Plant Physiology 134:748-757.

McCall, K.A., C.-C. Huang, and C.A. Fierke. 2000. Function and mechanism of zinc metalloenzymes. Journal of Nutrition 130:1437S-1446S

Merlin, C., M. Masters, S. McAteer, and A. Coulson. 2003. Why is carbonic anhydrase essential to Escherichia coli? Journal of Bacteriology 185:6415-6424.

Meldrum, N.U., and F.J.W. Roughton. 1933. Carbonic anhydrase: its properties. Journal of Physiology 80:113-142.

Mitsuhashi, S., T. Mizushima, E. Yamashita, M. Yamamoto, T. Kumasaka, H. Moriyama, et al. 2000. X-ray structure of betacarbonic anhydrase from the red alga, Porphyridium purpureum, reveals a novel catalytic site for $\mathrm{CO}_{2}$ hydration. Journal of Biological Chemistry 275:5521-5526.

Mitsuhashi, S., J. Ohnishi, M. Hayashi, and M. Ikeda. 2004. A gene homologous to beta-type carbonic anhydrase is essential for the growth of Corynebacterium glutamicum under atmospheric conditions. Applied Microbiology and Biotechnology 63:592601.

Moroney, J.V., S.G. Bartlett, and G. Samuelsson. 2001. Carbonic anhydrases in plants and algae. Plant Cell and Environment 24:141-153.

Nishimori, I., S. Onishi, H. Takeuchi, and C.T. Supuran. 2008. The alpha and beta classes carbonic anhydrases from Helicobacter pylori as novel drug targets. Current Pharmaceutical Design $14: 622-630$.
Neish, A. 1939. Studies on chloroplasts. Their chemical composition and the distribution of certain metabolites between the chloroplast and the remainder of the leaf. Biochemical Journal 33:300-308.

Ojeda-Barrios, D.L., O.A. Hernández-Rodríguez, J. MartínezTéllez, A. Núñez-Barrios, y E. Perea-Portillo. 2009. Aplicación foliar de quelato de zinc en nogal pecanero. Revista Chapingo Serie Especial Horticultura 15:205-210.

Papoyan, A., and L.V. Kochian. 2004. Identification of Thlapsi caerulescens genes that may be involved in heavy metal hyper accumulation and tolerance. Characterization of a novel heavy metal transporting ATPase. Plant Physiology 136:3814-3823.

Perea-Portillo, E., D.L. Ojeda-Barrios, O.A. Hernández-Rodríguez, D.J. Escudero-Almanza, J.J. Martínez-Téllez, y G.R. LópezOchoa. 2010. El zinc como promotor de crecimiento y fructificación en el nogal pecanero. Tecnociencia Chihuahua 4(2):64-71.

Rowlett, R.S. 2010. Structure and catalytic mechanism of the $\beta$-carbonic anhydrases. Biochimica et Biophysica Acta - Proteins and Proteomics 1804:362-373.

Sagardoy, R., F. Morales, A.F. López-Millán, A. Abadía, and J. Abadía. 2008. Effects of zinc toxicity in sugar beet (Beta vulgaris L.) Plants grown in hydroponics. Plant Biology 11:339-350.

Sasaki, H., T. Hirose, Y. Watanabe, and R. Ohsugi. 1998. Carbonic anhydrase activity and $\mathrm{CO}_{2}$ transfer resistance in $\mathrm{Zn}$-deficient rice leaves. Plant Physiology 118:929-934.

Smith, K.S., and J.G. Ferry. 2000. Prokaryotic carbonic anhydrases. FEMS Microbiology Review 24:335-366.

Snir, I. 1983. Carbonic anhydrase activity as an indicator of zinc deficiency in pecan leaves. Plant and Soil 74:287-289.

Srivastava, A.K., and S. Singh. 2009. Zinc nutrition in Nagpur mandarin on Haplustert. Plant Nutrition 32:1065-1081.

Stryer, L., J. Berg, M. Tymoczko, y L. John 2008. Bioquímica $6^{\circ}$ Universidad de Yale. Ed. Reverté, Barcelona, España.

Tiwari, S., M. Siwakoti, B. Adhikari, and K. Subedi. 2005. An inventory and assessment of invasive alien plant species of Nepal 114 p. The World Conservation Union IUCN, Kathmandu, Nepal.

Tobin, A.J. 1970. Carbonic anhydrase from parsley leaves. Journal of Biological Chemistry 245:2656-2666.

Vallee, B.L., and D.S. Auld. 1993. Cocatalytic zinc motifs in enzyme catalysis. National Academy of Science 90:2715-2718.

Weiss, D.J., F.D. Mason, F.J. Zhao, J.D. Kirk, B.J. Coles, and S.A. Horstwood. 2005. Isotopic discrimination of zinc in higher plants. New Phytologist 165:703-710.

Williams, R.J.P. 1987. The biochemistry of zinc. Polyhedron 6:6169. 